\title{
Mechanisms of uptake of radioactive labels by meiobenthic copepods during grazing experiments
}

\author{
Kevin R. Carman* \\ Department of Oceanography, Florida State University, Tallahassee, Florida 32306-3048, USA
}

\begin{abstract}
Use of labeled substrates as a tool for trophic studies in natural marine sediments was examined employing a variety of approaches. The temporal patterns of microbial incorporation of $\left[{ }^{14} \mathrm{C}\right]$ acetate and parallel uptake of ${ }^{14} \mathrm{C}$ from $\left[{ }^{14} \mathrm{C}\right]$-acetate by benthic copepods was not consistent with the patterns expected if copepods took up ${ }^{14} \mathrm{C}$ primarily due to grazing on labeled microbes. Further, in clasping pairs of Zausodes arenicolus, males (which do not feed while clasping) took up more label from $\left[{ }^{14} \mathrm{C}\right]$-acetate than did females (which continue to feed while clasped). In contrast, when $\left[{ }^{14} \mathrm{C}\right]$ bicarbonate was used as a tracer, ca $80 \%$ of the radioactivity was associated with females from clasping pairs of $Z$. arenicolus. The locations of radioactivity associated with copepods was determined with autoradiographs on copepod sections. Radioactivity from $\left[{ }^{14} \mathrm{C}\right]$-acetate was associated only with the cuticle of copepods, and concentrated in areas where epicuticular bacteria associated with the copepods tended to be most abundant. In contrast, radioactivity from $\left[{ }^{14} \mathrm{C}\right]$-bicarbonate was concentrated in the guts of copepods. Considered collectively, these observations indicate that uptake of label from $\left[{ }^{14} \mathrm{C}\right]-$ acetate by copepods was not the result of grazing on labeled sedimentary bacteria. Uptake of radioactivity from $\left[{ }^{14} \mathrm{C}\right]$-bicarbonate by copepods, however, was almost exclusively due to grazing on labeled photoautotrophs.
\end{abstract}

\section{INTRODUCTION}

Radioactive tracers have been used by several investigators as a probe to study trophic interactions between microbes and aquatic invertebrates under near-natural conditions (Hollibaugh et al. 1980, MeyerReil \& Faubel 1980, Montagna 1984a, Carman \& Thistle 1985, Montagna \& Bauer 1988, Carman et al. 1989). The goal of such investigations has been to determine the type and/or quantity of microorganisms consumed by invertebrate grazers; such a determination is based on the assumption that radioactivity in grazers is a function of the number of labeled microorganisms consumed. In addition to grazing on labeled microbes, radioactivity could become associated with grazers via absorption (direct uptake) of organic substrates or uptake of label by non-prey microorganisms associated with grazers (e.g. epicuticular or gut microorganisms).

\footnotetext{
- Present address: Department of Zoology and Physiology, Louisiana State University, Baton Rouge, Louisiana 708031725 , USA
}

In meiofaunal grazing studies, the possible importance of uptake of labels by non-feeding processes has been recognized (Montagna 1983, 1984a, b, Carman \& Thistle 1985, Montagna \& Bauer 1988, Carman et al. 1989), but incompletely evaluated. When $\left[{ }^{14} \mathrm{C}\right]$-bicarbonate is used as a tracer of grazing on microalgae, dark controls (incubated in the dark to prevent photosynthetic fixation) have been used to determine the proportion of radioactivity in grazers that is due to grazing on microalgae (e.g. Montagna 1984a, Carman \& Thistle 1985, Montagna \& Bauer 1988). It is possible, however, that photosynthetically active microalgae (e.g. diatoms, cyanobacteria) could be attached to the surface of grazers. If such were the case, dark controls would not allow a distinction between radioactivity in grazers that was due to uptake by ectocommensal microalgae versus radioactivity that resulted from grazing on sedimentary microalgae.

When using labeled organic substrates to monitor grazing on heterotrophic bacteria, one must consider the possibility that grazers directly incorporate the dissolved organic material (Anderson \& Stephens 1969, 
Brown \& Sibert 1977, Gyllenberg \& Lundqvist 1978, Lopez et al. 1979, Stewart 1979, Tempel \& Westheide 1980, Montagna 1983) or that label is taken up by heterotrophic bacteria attached to the grazer (Anderson \& Stephens 1969). Meiofaunal uptake of radioactivity due to non-feeding processes has previously been estimated under artificial conditions, including the use of metabolic inhibitors and the removal of animals from their natural environment (Montagna 1983, 1984a, b, Montagna \& Bauer 1988). Such control experiments demonstrate the potential mechanisms by which radioactivity from labeled substrates becomes associated with meiofauna, but do not necessarily reflect the actual mechanisms by which radioactivity is taken up by grazers under the less-contrived conditions used in in situ grazing studies (see Brock 1978). Stated differently, control experiments for uptake of label due to non-grazing processes should be conducted under the same conditions as the actual grazing experiments.

In the present study, analyses were performed to distinguish among uptake of radioactivity by benthic copepods during grazing experiments due to (1) ingestion of labeled microorganisms, (2) uptake by microorganisms attached to copepods, and (3) direct absorption of labeled substrates by copepods.

A time-course study was used to determine if the temporal patterns of uptake of ${ }^{14} \mathrm{C}$ from $\left[{ }^{14} \mathrm{C}\right]$-acetate by copepods were indicative of grazing on labeled microorganisms. The temporal patterns of uptake of radioactivity by copepods were interpreted based on theoretical considerations (Conover \& Francis 1973) and empirical observations of incorporation of $\left[{ }^{14} \mathrm{C}\right]$ acetate by sedimentary bacteria. Specifically, if radioactivity in copepods was due to grazing on labeled bacteria, an initial lag period (i.e. a delay in uptake of radioactivity) would be expected in uptake of radioactivity by copepods.

Second, uptake of radioactivity by clasping pairs of Zausodes arenicolus was examined. Clasping pairs of $Z$. arenicolus are formed when adult males, using specially adapted geniculating antennules (Dahms 1988), clasp juvenile females of their species as a precopulatory strategy. While clasped, juvenile females continue to feed (own obs.), but males are unable to feed because their feeding appendages are pressed against the juvenile female's dorsal cephalothorax (Kern et al. 1984, own obs.: see Fig. 1). Thus, radioactivity in males and females from clasping pairs was compared to allow a distinction between uptake of label by copepods due to grazing versus non-grazing processes.

Finally, radioactivity associated with copepods was localized with autoradiography on copepod sections. The distribution patterns of radioactivity on copepods were used to interpret the mechanisms by which radioactivity became associated with copepods.

\section{MATERIALS AND METHODS}

Study site. Field work for this study was performed in late October and early November, 1988, with sediment from a gently sloping, low-energy, intertidal site ca $1 \mathrm{~km}$ west of the Florida State University Marine Laboratory $\left(29^{\circ} 55.00^{\prime} \mathrm{N}, 84^{\circ} 30.36^{\prime} \mathrm{W}\right.$; described by Carman \& Thistle 1985). Cores of sediment were collected during low tides, at which time ca $20 \mathrm{~cm}$ of water overlay the sediment. Sediment at this site is a medium-fine quartz sand. Silt-clay and organic material are each less than $1 \%$ of sediment dry weight.

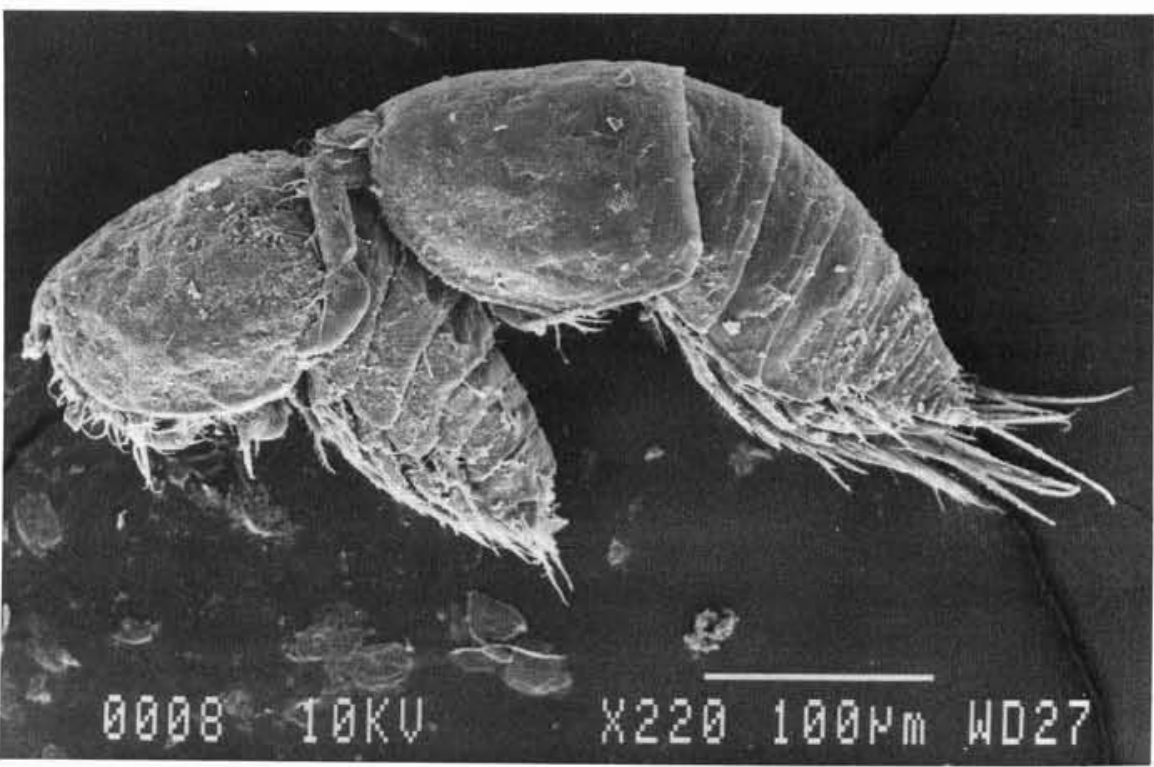

Fig. 1. Zausodes arenicolus, Scanning electron micrograph of a clasping pair. Male's mouth is covered by the dorsum of the female 
Approximately the top $5 \mathrm{~mm}$ of sediment are oxidized, below which occurs a sharp transition to anoxic conditions as indicated by darker-colored sediment and the smell of sulfide.

Experimental design. On 27 October 1988, eight $9.6 \mathrm{~cm}^{2}$ cores of sediment (core liners were $10 \mathrm{~cm}$ long and constructed of clear plastic) were collected at random from a $1 \mathrm{~m}^{2}$ region in a tide pool ca $30 \mathrm{~m}$ offshore. Water temperature was ca $25^{\circ} \mathrm{C}$ at the time of sampling. Overlying water was removed until $2 \mathrm{~cm}$ of water remained in each core. To each core, $15 \mu \mathrm{Ci}$ of $\mathrm{NaH}^{14} \mathrm{CO}_{3}\left(5.0 \mathrm{mCi} \mathrm{mmol}^{-1}\right)$ was administered by injection with a microliter syringe through a siliconsealed port on the side of the core (the 'injection' technique, described by Dobbs et al. 1989). Five cores were incubated under ambient sunlight for $4 \mathrm{~h}$, and 3 cores were incubated in the dark as controls. At the end of the incubation period, the water overlying the sediment and the top $1 \mathrm{~cm}$ of sediment were preserved in $3 \%$ gluteraldehyde (gluteraldehyde:seawater; final concentration).

On 1 November 1988,42 cores of sediment $\left(9.6 \mathrm{~cm}^{2}\right)$ were collected as described above, and at approximately the same location in the tide pool. The sediment cores were immediately transferred to the F.S.U. Marine Laboratory. Twenty-one cores were used to determine the temporal pattern of uptake of label from $\left[{ }^{14} \mathrm{C}\right]$-acetate by benthic copepods; 21 cores were used for a parallel determination of the temporal pattern of incorporation of $\left[{ }^{14} \mathrm{C}\right]$-acetate into lipids of sedimentary organisms. For both uptake of label by copepods and incorporation of label into lipids, 3 cores were randomly assigned to one of 7 incubation periods: $0,30,60,120$, 180,240 , and $360 \mathrm{~min}$. Time- 0 incubations served as poisoned ( $3 \%$ gluteraldehyde) controls for abiotic uptake of label. Cores used to monitor uptake of label by copepods were injected (as described above) with $5 \mu \mathrm{Ci}$ of $\left[1,2-{ }^{14} \mathrm{C}\right]$-acetate $\left(110 \mathrm{mCi} \mathrm{mmol}^{-1}\right)$. Cores used to monitor incorporation of label into lipids were injected with $1 \mu \mathrm{Ci}$ of $\left[1,2-{ }^{14} \mathrm{C}\right]$-acetate $(110 \mathrm{mCi}$ $\left.\mathrm{mmol}^{-1}\right)$. The $1 \mu \mathrm{Ci}$ of $\left[{ }^{14} \mathrm{C}\right]$-acetate was amended with non-radioactive sodium acetate so that the total molar concentration of acetate used in cores designated for incorporation of label into lipids was equivalent to the acetate concentration used in cores designated for uptake of label by copepods. All cores were incubated in the dark to prevent photosynthetic fixation of respired ${ }^{14} \mathrm{CO}_{2}$.

At the end of an incubation period, the overlying water and top $1 \mathrm{~cm}$ of sediment from cores designated for uptake of label by copepods were preserved as described above. Sediment incubations designated for incorporation of label into lipids were terminated by removing the overlying water and extruding the top $1 \mathrm{~cm}$ of sediment into a jar containing chloro- form: methanol: phosphate-buffer solution (10 $\mathrm{ml}: 20$ $\mathrm{ml}: 8 \mathrm{ml})$.

Laboratory treatment of copepods. Copepods were separated from the sediment and concentrated on a $62 \mu \mathrm{m}$ sieve with the Barnett (1968) troughing procedure. Copepods were stained with Rose Bengal and sorted under a dissecting microscope. Three copepod species were abundant and present in all cores. Adults of Halicyclops coulli $(20.0 \pm 7.2$ : mean \pm 1 SD individuals $\left.10 \mathrm{~cm}^{-2}\right)$, Robertsonia sp. $(18.2 \pm 5.2)$, and adults $(38.2 \pm 17.2)$ and clasping pairs $(10.2 \pm 6.5)$ of Zausodes arenicolus (see 'Introduction') were rinsed 3 times in distilled water, then stored at $4{ }^{\circ} \mathrm{C}$ in separate vials containing $3 \%$ gluteraldehyde. Uptake of radioactivity by males and females of clasping pairs was determined by teasing apart the pair and separately quantifying radioactivity in males and females. Total radioactivity in copepods was determined by pooling individuals from each core prior to analysis (Carman \& Thistle 1985). Pooled copepods were solubilized with TS-1 tissue solubilizer (Research Products International), and the digest was neutralized with $0.1 \mathrm{~N} \mathrm{HCl}$.

Lipids. Lipids were extracted from sediments according to the method of White et al. (1979). Bulk lipids were separated into nonpolar (neutral) and polar (phospho- and glyco-) lipid fractions (Guckert et al. 1985) with prepacked, $3 \mathrm{ml}, 500 \mathrm{mg}$ silicic-acid columns (Thomas Scientific). The temporal pattern of bacterial incorporation of $\left[{ }^{14} \mathrm{C}\right]$-acetate was estimated from the incorporation of ${ }^{14} \mathrm{C}$ into polar-lipid fractions (Findlay \& White 1984). The temporal pattern of the transfer of ${ }^{14} \mathrm{C}$ from bacteria to grazers was estimated from the incorporation of ${ }^{14} \mathrm{C}$ into neutral lipids. This criterion was used because, while bacteria use acetate to synthesize polar lipids for membranes and storage products, relatively little nonpolar lipid is produced by bacteria (Gehron \& White 1982). Nonpolar lipids are, however, an important storage product of eukaryotes (e.g. Benson et al. 1973, Gehron \& White 1982).

Quantification of radioactivity. Bio-Safe II (Research Products International) was used as a scintillation cocktail for copepod digests and lipid fractions. Radioactivity was quantified with an LKB Wallac liquid scintillation counter (Model 1217). Counts per minute (cpm) were converted to disintegrations per minute (dpm) by the method of external standards-channels ratio.

Copepod sectioning. From sediment cores inoculated with $\left[{ }^{14} \mathrm{C}\right]$-acetate and incubated for $0,120,180$, 240 , and $360 \mathrm{~min}, 2$ to 4 individuals from each species were saved for analysis by scanning electron microscopy, or for sectioning and microautoradiography. A few individuals from each of the cores inoculated with $\mathrm{NaH}^{14} \mathrm{CO}_{3}$ were also saved for sectioning and microautoradiography. 
Microautoradiography on longitudinal copepod sections was used to localize radioactivity. Copepods were sectioned following the general procedure described by Williams-Howze et al. (1987). Copepods preserved in $3 \%$ gluteraldehyde were post-fixed in $1 \% \mathrm{OsO}_{4}$, rinsed in $1 \%$ sucrose, then dehydrated in a graded ethanol series according to the procedure described by Felgenhauer (1987). Individual copepods were placed in gelatin capsules filled with L. R. White resin (Ted Pella, Inc.). The capsules were capped and placed in test tubes. The copepods were infiltrated with resin for $24 \mathrm{~h}$. Capsules were placed in an oven, and the resin was hardened at $60^{\circ} \mathrm{C}$ for $24 \mathrm{~h}$. Sections ( 2 to $3 \mu \mathrm{m}$ in thickness) were cut with glass knives on an MT-2 ultramicrotome (Sorvall). Using a fine tungsten wire, individual sections were transferred to a small drop of water (about $5 \mu \mathrm{l}$ ) on an acid-cleaned slide. Sections from a single copepod were arranged on a single slide. Sections were fixed to slides by heating for $24 \mathrm{~h}$ at $70{ }^{\circ} \mathrm{C}$.

Microautoradiography on copepod sections. In the darkroom, NTB-2 emulsion (Kodak) diluted 2:1 with distilled water (this dilution yields an emulsion layer 1 to $2 \mu \mathrm{m}$ thick [Rogers 1977 ]) was maintained at $43^{\circ} \mathrm{C}$. In total darkness, a slide was dipped into a $30 \mathrm{ml}$ beaker containing the emulsion and allowed to drain in a vertical position for $20 \mathrm{~s}$. The slide was held horizontally and the back side of the slide was wiped clean. The slide was placed (face up) on a cold metal plate.

Approximately $30 \mathrm{~min}$ after processing the last slide in a batch, the slides were removed from the cold plate and placed on a paper towel to dry. After $1 \mathrm{~h}$ of drying, slides were placed in a slide box, and the box was placed in a desiccator containing silica-gel desiccant. The following morning a packet of silica-gel desiccant was placed in, and a cover on the slide box. The box was wrapped in 2 layers of aluminum foil and placed in a refrigerator at $4{ }^{\circ} \mathrm{C}$. Slides were exposed for $10 \mathrm{~d}$ under these conditions.

Slides were developed with Dektol (Kodak) (1 part stock solution diluted with 2 parts distilled water) for $2 \mathrm{~min}$ at $17^{\circ} \mathrm{C}$. Development was terminated by placing slides in $30 \%$ sodium thiosulphate ('hypo') for $8 \mathrm{~min}$. Slides were then washed in running tapwater for $15 \mathrm{~min}$. The entire development procedure was carried out in total darkness. The developed slides were dried thoroughly in a desiccator.

Microautoradiographs were examined with brightfield illumination at $400 \times$. No attempt was made to count silver grains, but areas of concentrated radioactivity were easily identified by dense aggregations of silver grains. Locations of radioactivity for each specimen were tabulated and used for interpretation of the mechanism(s) by which radioactivity became associated with the copepod.
Scanning electron microscopy. Scanning electron microscopy (SEM) was used to determine the presence and location of epicuticular microorganisms on copepods. Copepods were prepared for SEM according to the procedure described by Felgenhauer (1987). Specimens were coated with carbon, sputter-coated with gold-palladium, and examined using a JEOL-8402 scanning electron microscope.

\section{RESULTS}

\section{Temporal patterns of $\left[{ }^{14} \mathrm{C}\right]$-acetate uptake}

The temporal patterns of incorporation of $\left[{ }^{14} \mathrm{C}\right]$-acetate into lipid fractions are presented in Fig. 2A. Incorporation of ${ }^{14} \mathrm{C}$ into polar and neutral-lipid fractions was linear over incubation times from 0 to $240 \mathrm{~min}$ $\left(R^{2}=0.487, p=0.0013\right)$, and most radioactivity was present in the polar-lipid fraction. From 240 to $360 \mathrm{~min}$, ${ }^{14} \mathrm{C}$ in the polar-lipid fraction decreased, apparently
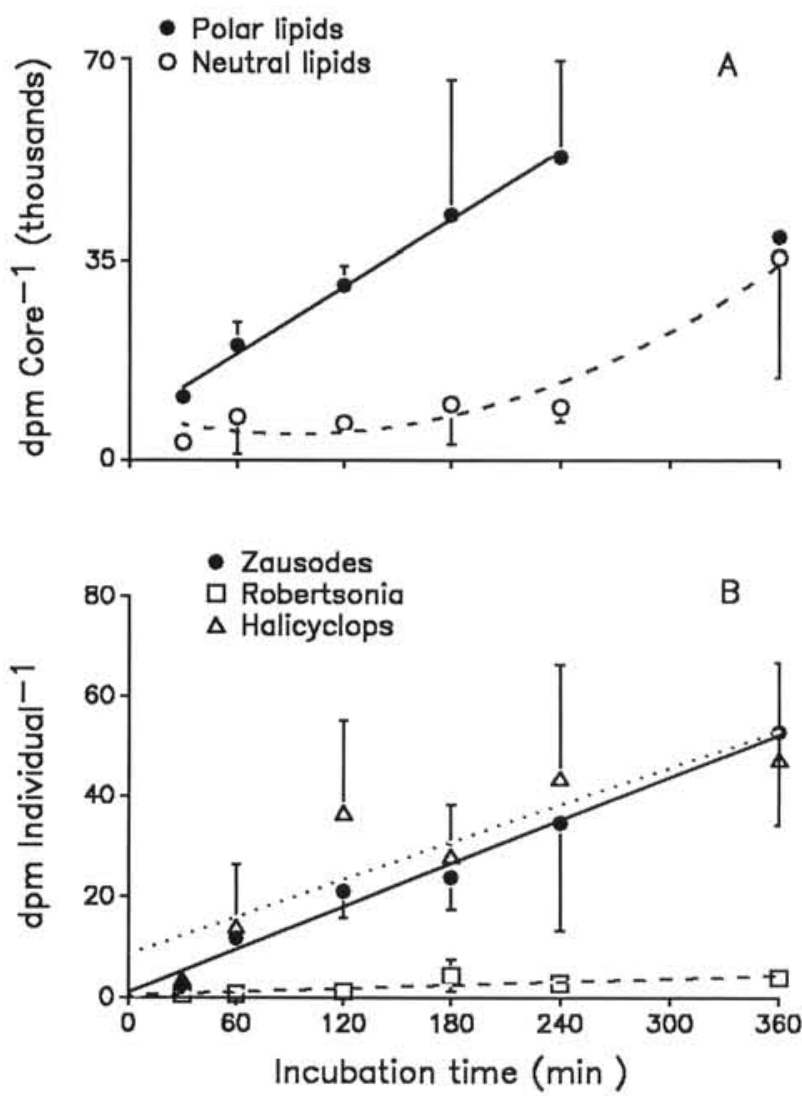

Fig. 2. (A) Incorporation of $\left[{ }^{14} \mathrm{C}\right]$-acetate into polar- and nonpolar-lipid fractions from intact cores of sediment as a function of incubation time; means $\pm 1 \mathrm{SD}$ of 3 replicates; lines represent best-fit regression models (see text for details). (B) Uptake of radioactivity from $\left[{ }^{14} \mathrm{C}\right]$-acetate by 3 copepod species in intact cores of sediment; means $\pm 1 \mathrm{SD}$ of 3 replicates; lines represent best-fit regression models (see text for details) 
because of limited substrate availability. Incorporation of ${ }^{14} \mathrm{C}$ into the neutral-lipid fraction was relatively low over incubation periods from 30 to $240 \mathrm{~min}$, then increased markedly between 240 and $360 \mathrm{~min}$ (Fig. 2A). A quadratic equation provided the best-fit regression model $\left(\mathrm{R}^{2}=0.645, \mathrm{p}=0.0018\right)$.

The temporal patterns of uptake of ${ }^{14} \mathrm{C}$ from $\left[{ }^{14} \mathrm{C}\right]$ acetate by adult copepods is presented in Fig. 2B. Although the data were quite variable, uptake of ${ }^{14} \mathrm{C}$ by Halicyclops coulli and Zausodes arenicolus was similar. Uptake of ${ }^{14} \mathrm{C}$ by Robertsonia sp. was relatively low throughout the range of incubation periods, and never exceeded an average of $5 \mathrm{dpm}$ individual $^{-1}$. In all 3 species, uptake of radioactivity over time was best described by a linear regression model, i.e. the quadratic term was not significant $\left(H\right.$. coulli: $\mathrm{R}^{2}=0.463, \mathrm{p}=$ $0.0019 ; Z$. arenicolus: $\mathrm{R}^{2}=0.713, \mathrm{p}=0.0001$; Robertsonia sp.: $\mathrm{R}^{2}=0.383, \mathrm{p}=0.0062$ ). Thus, in contrast to the apparent lag in incorporation of ${ }^{14} \mathrm{C}$ into the neutral-lipid fraction (Fig. 2A), there was no evidence for a lag in uptake of radioactivity by any of the copepod species examined.

\section{Uptake of ${ }^{14} \mathrm{C}$ from $\left[{ }^{14} \mathrm{C}\right]$-bicarbonate}

Among the 3 species, Robertsonia sp. consistently contained the highest levels of radioactivity (mean \pm $1 \mathrm{SD}=387+216 \mathrm{dpm}$ ind $\left.^{-1}\right)$, whereas radioactivity in Zausodes arenicolus $\left(60 \pm 40 \mathrm{dpm}^{\text {ind. }}{ }^{-1}\right)$ and Halicyclops coulli ( $53 \pm 15 \mathrm{dpm}$ ind. ${ }^{-1}$ ) was lower and approximately equivalent.

\section{Radioactivity in Zausodes clasping pairs}

Uptake of ${ }^{14} \mathrm{C}$ from $\left[{ }^{14} \mathrm{C}\right]$-acetate by males and females from clasping pairs of Zausodes arenicolus is shown in Fig. 3. Over incubation times ranging from 30 to 360 min, males from clasping pairs consistently took up more radioactivity than did females. The percentage of radioactivity in males, however, gradually decreased over time from $72 \%$ at $30 \mathrm{~min}$ to $54 \%$ at $360 \mathrm{~min}$. In contrast to uptake of ${ }^{14} \mathrm{C}$ from $\left[{ }^{14} \mathrm{C}\right]$-acetate, most (mean $\pm 1 \mathrm{SD}=84.2 \% \pm 6.1 \%){ }^{14} \mathrm{C}$ from $\left[{ }^{14} \mathrm{C}\right]$-bicarbonate in clasping pairs was associated with juvenile females.

\section{SEM examination of copepods}

A minimum of 5 adults from each of Zausodes arenicolus, Halicyclops coulli, and Robertsonia sp. were examined with SEM. Although no attempt was made to count the number of microorganisms attached to copepod cuticles, several consistent patterns were

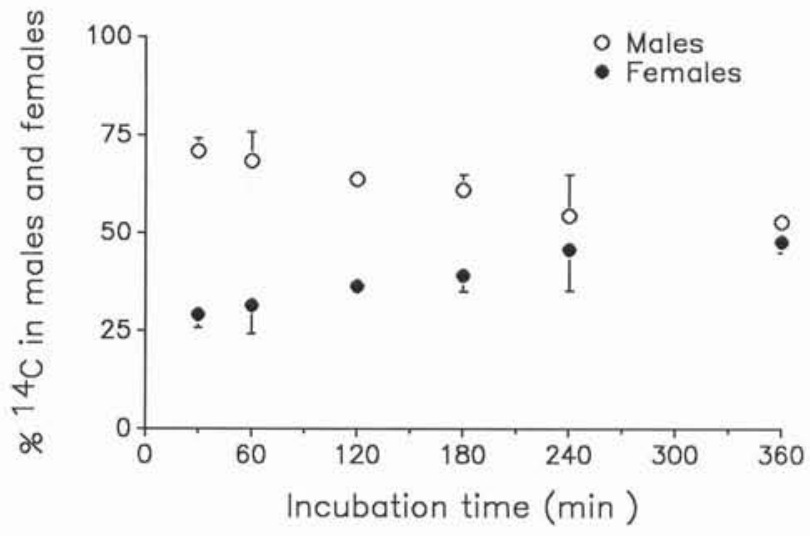

Fig. 3. Zausodes arenicolus. Uptake of ${ }^{14} \mathrm{C}$ from $\left[{ }^{14} \mathrm{C}\right]$-acetate by males and females from clasping pairs in intact cores of sediment over a range of incubation times. Data are expressed as percentage of radioactivity recovered in males and females relative to the total amount of radioactivity in clasping pairs. Means $\pm 1 \mathrm{SD}$ of 3 replicates

apparent. Bacteria attached to the dorsal cephalothorax and mesosome of copepods were rare, and present only as single cells, not colonies or chains. Dense aggregations of bacteria were frequently observed in intersegmental depressions on the urosome (Fig. 4A), on the legs (Fig. 4B), and on the ventral cephalothorax (around the mouth parts) (Fig. 4C). These patterns were consistent among the 3 species.

Among all the copepods examined with SEM, only 1 diatom was observed attached to a copepod exoskeleton. A chain-forming microorganism was commonly observed on Zausodes and Robertsonia (Fig. 4A).

\section{Autoradiography on copepod sections}

The locations of radioactivity associated with individuals of Zausodes arenicolus, Halicyclops coulli, and Robertsonia sp. are presented in Table 1. In incubations with $\left[{ }^{14} \mathrm{C}\right]$-acetate, the location of radioactivity on copepods was consistent over the incubation periods examined. Thus, the data in Table 1 summarize all observations of copepods over the incubation periods of 120 to $360 \mathrm{~min}$. No radioactivity (i.e. aggregations of silver grains) was observed in time- 0 controls from $\left[{ }^{14} \mathrm{C}\right]$-acetate incubations or dark controls from $\left[{ }^{14} \mathrm{C}\right]$ bicarbonate incubations.

A consistent pattern, independent of copepod species, was apparent in the location of radioactivity on copepods incubated with $\left[{ }^{14} \mathrm{C}\right]$-acetate. All individuals in which detectable radioactivity was present exhibited aggregations of silver grains in discrete epicuticular regions (Figs. 5A, 6A \& 7A). In approximately twothirds of the copepods examined, radioactivity was concentrated around the mouth parts and legs. In 

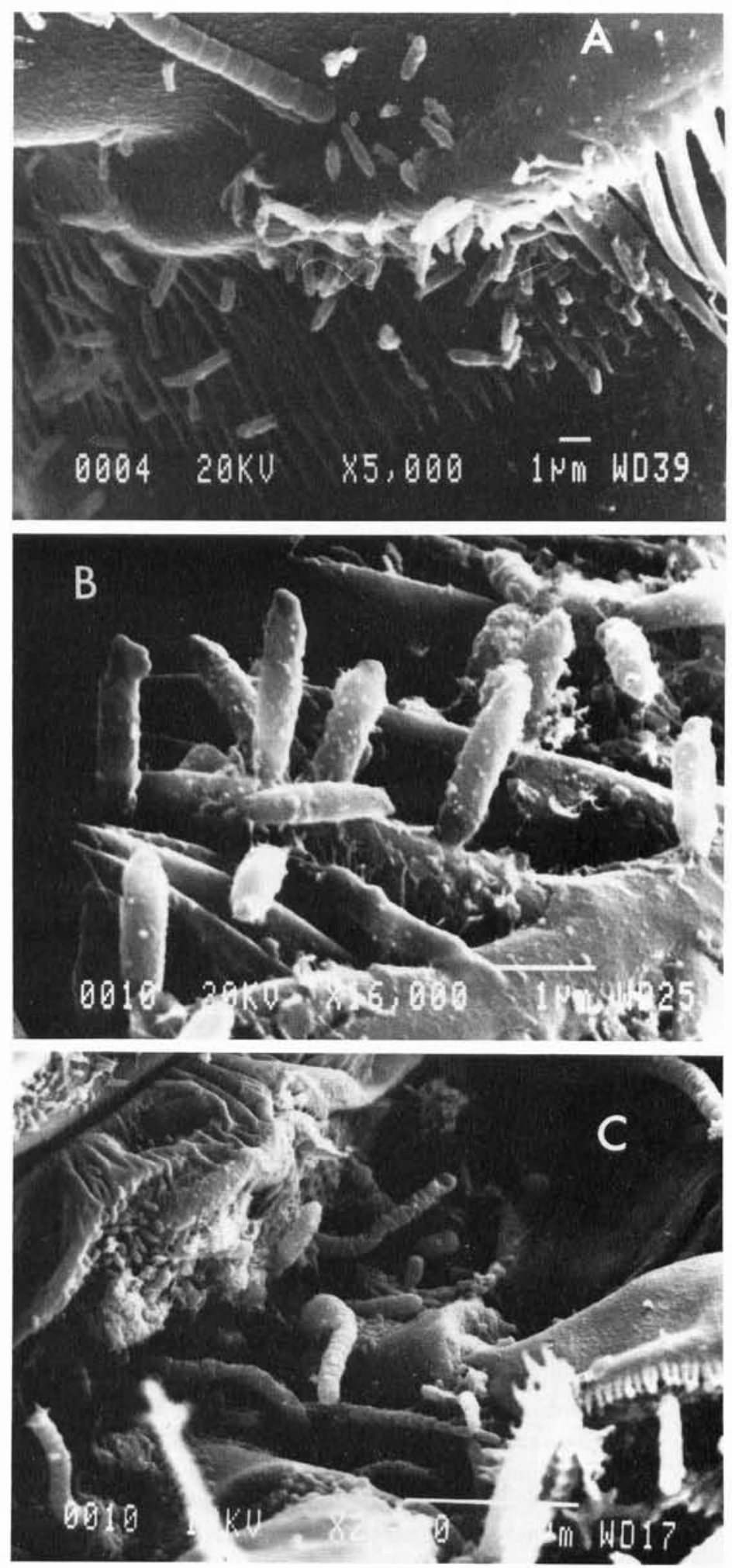

Fig. 4. Scanning electron micrograph of epicuticular bacteria on (A) urosome of Robertsonia sp. (scale bar = $1 \mu \mathrm{m}$ ), (B) legs (P1) of Zausodes arenicolus (scale bar = $1 \mu \mathrm{m}) ;(C)$ ventral cephalothorax (around the mouth parts) of $Z$. arenicolus (scale bar $=10 \mu \mathrm{m}$ ) one-third of the individuals examined, radioactivity was observed in intersegmental areas (both dorsal and ventral), particularly on the urosome. In 6 out of 11 Robertsonia sp. examined, no radioactivity could be detected. Only 2 out of 48 copepods examined had a detectable amount of radioactivity in their gut; both of these individuals were Zausodes arenicolus adults (Table 1). In Zausodes clasping pairs, radioactivity was 
Table 1. Location of radioactivity based on autoradiographic analysis of copepod sections from tracer experiments in intact cores of sediment. Incubations with $\left[{ }^{14} \mathrm{C}\right]$-acetate and $\left[{ }^{14} \mathrm{C}\right]$ bicarbonate are listed separately. Number of individuals examined for each species shown in parentheses. 'Gut' includes any radioactivity observed inside the body cavity. ND: no radioactivity detected

\begin{tabular}{|c|c|c|c|c|c|c|}
\hline & & \multicolumn{5}{|c|}{ Location of radioactivity } \\
\hline & & Mouth & Legs & Segments & Gut & ND \\
\hline \multicolumn{7}{|c|}{$\left[{ }^{14} \mathrm{C}\right]$-acetate } \\
\hline Halicyclops & (10) & 6 & 7 & 4 & 0 & 1 \\
\hline Robertsonia & (11) & 4 & 3 & 1 & 0 & 6 \\
\hline \multicolumn{7}{|l|}{ Zausodes } \\
\hline Adults & (16) & 11 & 12 & 8 & 2 & 1 \\
\hline Pairs: & (6) & & & & & \\
\hline males & & 5 & 5 & 2 & 0 & 1 \\
\hline females & & 5 & 5 & 1 & 0 & 1 \\
\hline Totals & $(48)$ & 31 & 32 & 16 & 2 & 10 \\
\hline \multicolumn{7}{|c|}{$\left[{ }^{14} \mathrm{C}\right]$-bicarbonate } \\
\hline Halicyclops & (5) & 0 & 0 & 0 & 3 & 2 \\
\hline Robertsonia & (5) & 0 & 0 & 0 & 4 & 1 \\
\hline \multicolumn{7}{|l|}{ Zausodes } \\
\hline Adults & (5) & 0 & 0 & 0 & 4 & 1 \\
\hline Pairs: & (5) & & & & & \\
\hline males & & 0 & 0 & 0 & 1 & 4 \\
\hline females & & 0 & 0 & 0 & 4 & 1 \\
\hline Totals & (25) & 0 & 0 & 0 & 16 & 9 \\
\hline
\end{tabular}

detected in both males and females (Fig. 8A), and the patterns of localization did not differ from $Z$. arenicolus adults or the other 2 species.

When cores of sediment were incubated with $\left[{ }^{14} \mathrm{C}\right]-$ bicarbonate, the location of radioactivity associated with copepods differed dramatically from the patterns observed when incubations were performed with $\left[{ }^{14} \mathrm{C}\right]$ acetate. In no case were aggregations of silver grains observed in epicuticular regions. Instead, when radioactivity was detected, it was consistently located within the body cavity of the copepod (Figs. 5B, 6B \& 7B). Radioactivity was detected in 4 out of 5 Zausodes arenicolus clasping pairs. Among these 4, radioactivity was associated only with the juvenile female in 3 instances (Fig. 8B). In one clasping pair, in addition to radioactivity associated with the juvenile female, a discrete bolus of radioactivity was observed in the gut of the male.

In both Robertsonia sp. and Zausodes arenicolus, radioactivity from $\left[{ }^{14} \mathrm{C}\right]$-bicarbonate tended to be concentrated in the gut but distributed throughout the body cavity (Figs. 6B, 7B). This pattern was in contrast to that observed for Halicyclops coulli, where radioactivity was present only in the gut, and only in discrete areas (Fig. 5B).

\section{DISCUSSION}

The time-course study was performed to determine if uptake of ${ }^{14} \mathrm{C}$ from $\left[{ }^{14} \mathrm{C}\right]$-acetate by copepods was consistent with the pattern expected if uptake of label were due to grazing on labeled bacteria. Based on the theoretical model of Conover \& Francis (1973), a lag period is expected between the time a labeled substrate is added to a sample and the time at which appreciable amounts of label begin to accumulate in grazers. Thus, if uptake of label by bacteria is linear over time, uptake of label by grazers should be hyperbolic over time if uptake is due to grazing on labeled bacteria. Such a pattern was reported by Montagna (1984a), who reported a rapid increase in meiofaunal (polychaete, copepod, and nematode) uptake of radioactivity from $\left[{ }^{14} \mathrm{C}\right]$-glucose between incubation periods of 4 and $8 \mathrm{~h}$. Montagna's (1984a) conclusions, however, were based on observations from only 3 incubation periods, 1, 4, and $8 \mathrm{~h}$, and the $8 \mathrm{~h}$ incubations were performed on a separate day from the 1 and $4 \mathrm{~h}$ incubations. Given the small number of incubation periods and the possible confounding influence of performing incubations on different days, Montagna's conclusion that uptake of label by meiofauna was hyperbolic, and thus reflected grazing on labeled bacteria, seems premature.

In the present study, incorporation of $\left[{ }^{14} \mathrm{C}\right]$-acetate into polar lipids indicated that bacterial incorporation of label was linear over the first $4 \mathrm{~h}$ of incubation (Fig. 2A). The decrease from 4 to $6 \mathrm{~h}$ in the amount of label recovered in polar lipids was possibly due to exhaustion of the $\left[{ }^{14} \mathrm{C}\right]$-acetate and turnover of bacterial membrane lipids. Carbon-14 in neutral lipids lagged over the first $4 \mathrm{~h}$ of incubation but increased ca 3 -fold between the incubation periods of 4 and $6 \mathrm{~h}$. If incorporation of ${ }^{14} \mathrm{C}$ into neutral lipids was a valid indicator of transfer of bacterial biomass to grazers, and radioactivity in copepods was from grazing on labeled bacteria, one might expect to see in copepods a pattern similar to that observed in neutral lipids. In none of the 3 copepod species examined, however, was there any evidence of a lag period in uptake of ${ }^{14} \mathrm{C}$ from $\left[{ }^{14} \mathrm{C}\right]$ acetate (Fig. 2B); i.e. uptake of label by copepods was a linear, and not a hyperbolic function of time. These observations, then, do not support the hypothesis that radioactivity in copepods is the result of grazing on labeled bacteria.

Although the uptake of label by copepods was not consistent with theoretical expectations for grazing activity, the temporal pattern of label incorporation into neutral and polar lipids did indicate that bacterial biomass was transferred to eukaryotic consumers. As only copepods were examined in this study, the identity of these putative bacterial grazers cannot be determined. 

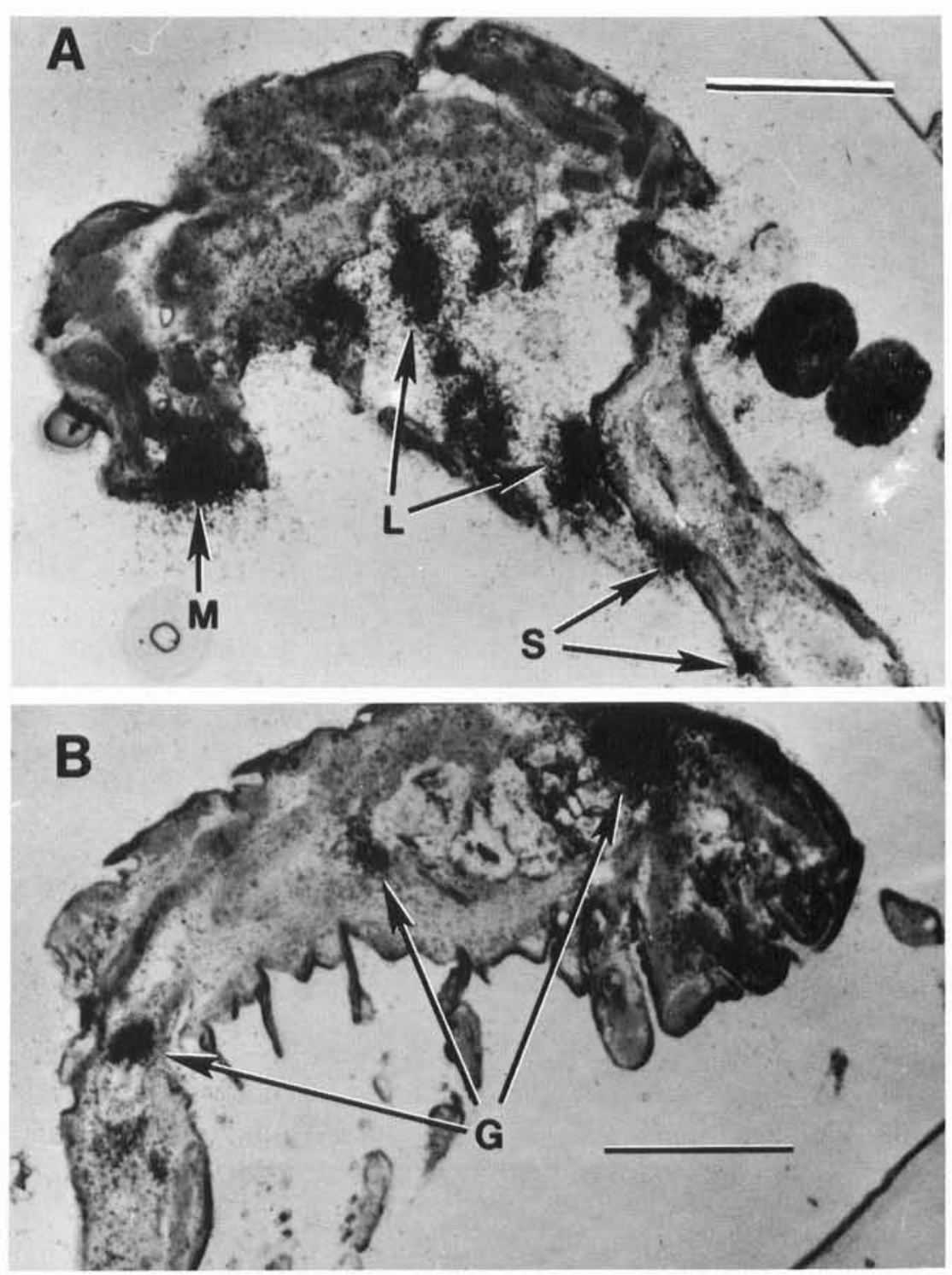

Fig. 5. Halicyclops coulli. Autoradiography on sections of an individual from an intact core of sediment. Scale bars = $100 \mu \mathrm{m}$. (A) Following incubation with $\left[{ }^{14} \mathrm{C}\right]$-acetate; note development of silver grains around the mouth parts (M), legs (L), and between segments on the urosome (S). (B) Following incubation with $\left[{ }^{14} \mathrm{C}\right]$-bicarbonate. Arrows indicate locations of radioactivity within the gut $(\mathrm{G})$
It is possible that other meiofaunal taxa (e.g. nematodes) or protozoans that were present in the sediment were responsible for the apparent grazing signal.

Uptake of ${ }^{14} \mathrm{C}$ from $\left[{ }^{14} \mathrm{C}\right]$-acetate by clasping pairs of Zausodes arenicolus (Fig. 3) provided further, more compelling evidence that radioactivity associated with copepods incubated with $\left[{ }^{14} \mathrm{C}\right]$-acetate was predominantly due to non-feeding processes. Because males clasped to juvenile females are unable to feed (Kern et al. 1984, own obs.), if uptake of label by copepods were due to grazing, one would expect to find radioactivity associated only with the juvenile-female component of the clasping pair. However, over incubation times from $30 \mathrm{~min}$ to $6 \mathrm{~h}$, more radioactivity from $\left[{ }^{14} \mathrm{C}\right]$-acetate was associated with males than with females from clasping pairs. This observation suggests that uptake of label by copepods due to non-feeding processes was responsible for much of the radioactivity from $\left[{ }^{14} \mathrm{C}\right]$-acetate associated with copepods. In contrast to the pattern observed when sediment was incubated with $\left[{ }^{14} \mathrm{C}\right]$ acetate, over $80 \%$ of the radioactivity in Zausodes pairs was associated with juvenile females when sediment was incubated with $\left[{ }^{14} \mathrm{C}\right]$-bicarbonate. This observation is consistent with the hypothesis that uptake of label from $\left[{ }^{14} \mathrm{C}\right]$-bicarbonate was predominantly due to grazing on labeled microalgae.

Thus, the partitioning of radioactivity between males and females of clasping Zausodes arenicolus pairs, as well as the kinetics of uptake of label by adult copepods, suggests that $\left[{ }^{14} \mathrm{C}\right]$-acetate became associated with copepods by means other than grazing or labeled bacteria. These data, however, do not providt an explanation of the mechanism(s) responsible for 


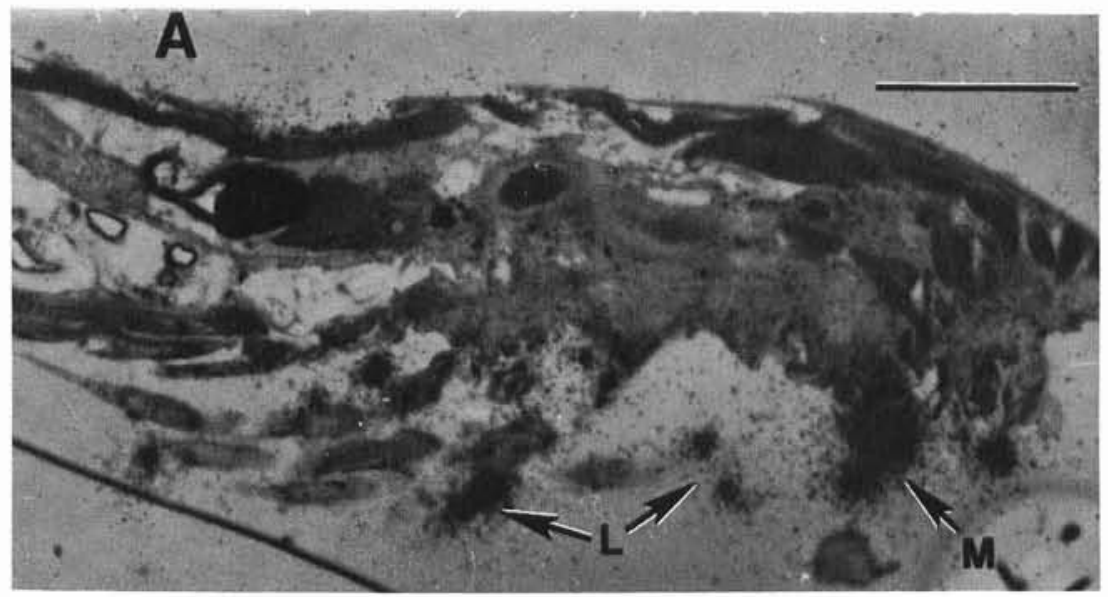

Fig. 6. Robertsonia sp. Autoradiography on sections of an individual from an intact core of sediment. Scale bars $=100 \mu \mathrm{m}$. (A) Following incubation with $\left[{ }^{14} \mathrm{C}\right]$-acetate; note development of silver grains around the mouth parts (M) and legs (L). (B) Following incubation with $\left[{ }^{14} \mathrm{C}\right]$ bicarbonate; the specimen is almost blackened by the developed silver grains; radioactivity is distributed throughout the inside of the copepod, but particularly concentrated in the gut (G)

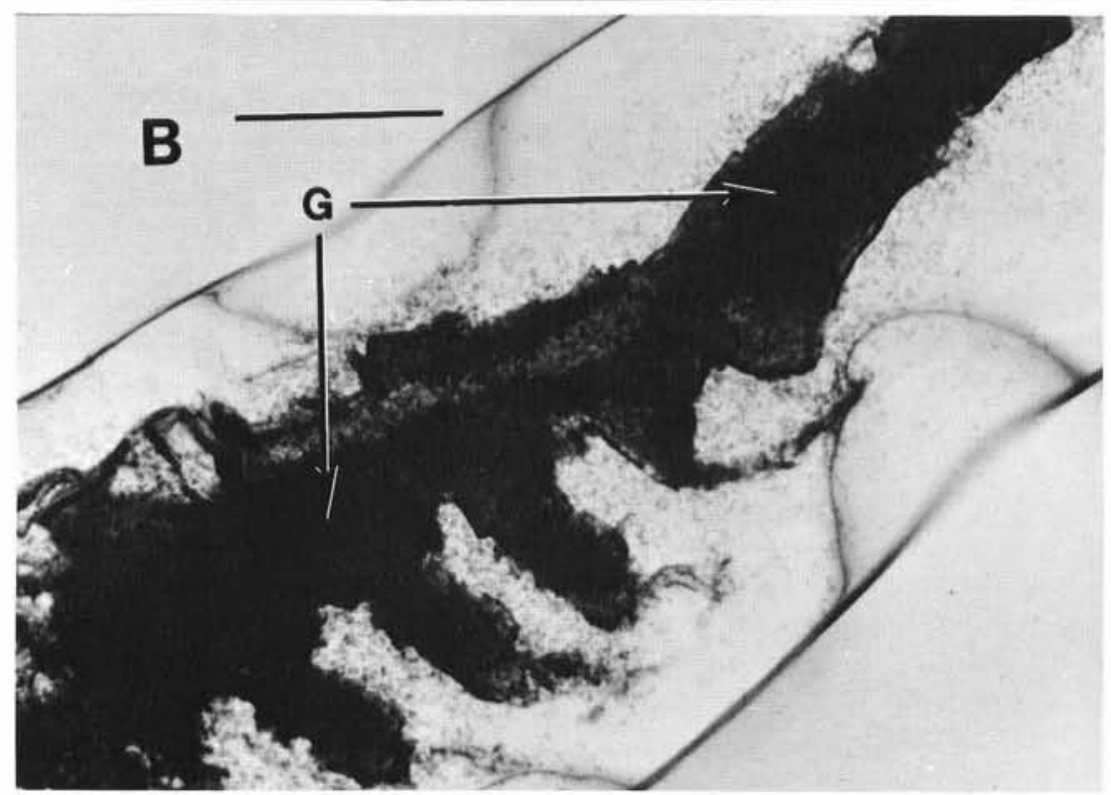

uptake of $\left[{ }^{14} \mathrm{C}\right]$-acetate by copepods. The localization of radioactivity on copepods with autoradiography provided further insight into this question.

Autoradiographic analysis of copepod sections confirmed that uptake of ${ }^{14} \mathrm{C}$ from $\left[{ }^{14} \mathrm{C}\right]$-acetate was not a consequence of grazing on labeled microorganisms (Figs. 5A to $8 \mathrm{~A}$ ). For all 3 species, radioactivity from $\left[{ }^{14} \mathrm{C}\right]$-acetate was concentrated at sites on copepods where epicuticular microorganisms tended to be most abundant, as indicated from SEM analyses (Fig. 4). There was no evidence that copepods directly absorbed $\left[{ }^{14} \mathrm{C}\right]$-acetate, because essentially no radioactivity was observed inside the body of any of the 3 species. This observation also indicates that gut bacteria were not responsible for uptake of $\left[{ }^{14} \mathrm{C}\right]$-acetate.

Autoradiographs on copepods from sediments incubated with $\left[{ }^{14} \mathrm{C}\right]$-bicarbonate (Fig. $5 \mathrm{~B}$ to $8 \mathrm{~B}$ ) contrasted with those from sediments incubated with $\left[{ }^{14} \mathrm{C}\right]$-acetate and provided a positive control for the autoradio- graphic technique. For all 3 species, radioactivity from $\left[{ }^{14} \mathrm{C}\right]$-bicarbonate was located on the inside of the copepod and concentrated in the gut. The detection of internal radioactivity from $\left[{ }^{14} \mathrm{C}\right]$-bicarbonate shows that if ${ }^{14} \mathrm{C}$ from $\left[{ }^{14} \mathrm{C}\right]$-acetate had been present in the gut of copepods it would have been detected with autoradiography. In contrast to copepods from samples that were incubated with $\left[{ }^{14} \mathrm{C}\right]$-acetate, in no case was radioactivity from $\left[{ }^{14} \mathrm{C}\right]$-bicarbonate concentrated in epicuticular areas.

Autoradiographs on clasping pairs of Zausodes arenicolus indicated that radioactivity from $\left[{ }^{14} \mathrm{C}\right]$-acetate associated with both males and females was due to uptake by epicuticular bacteria (Fig. 8A). Further, in clasping pairs of Zausodes, most radioactivity from $\left[{ }^{14} \mathrm{C}\right]$-bicarbonate was associated with juvenile females (Fig. 8B). In the one instance in which ${ }^{14} \mathrm{C}$ from $\left[{ }^{14} \mathrm{C}\right]-$ bicarbonate was observed in the male of the pair, the radioactivity was present in the gut. This observation 

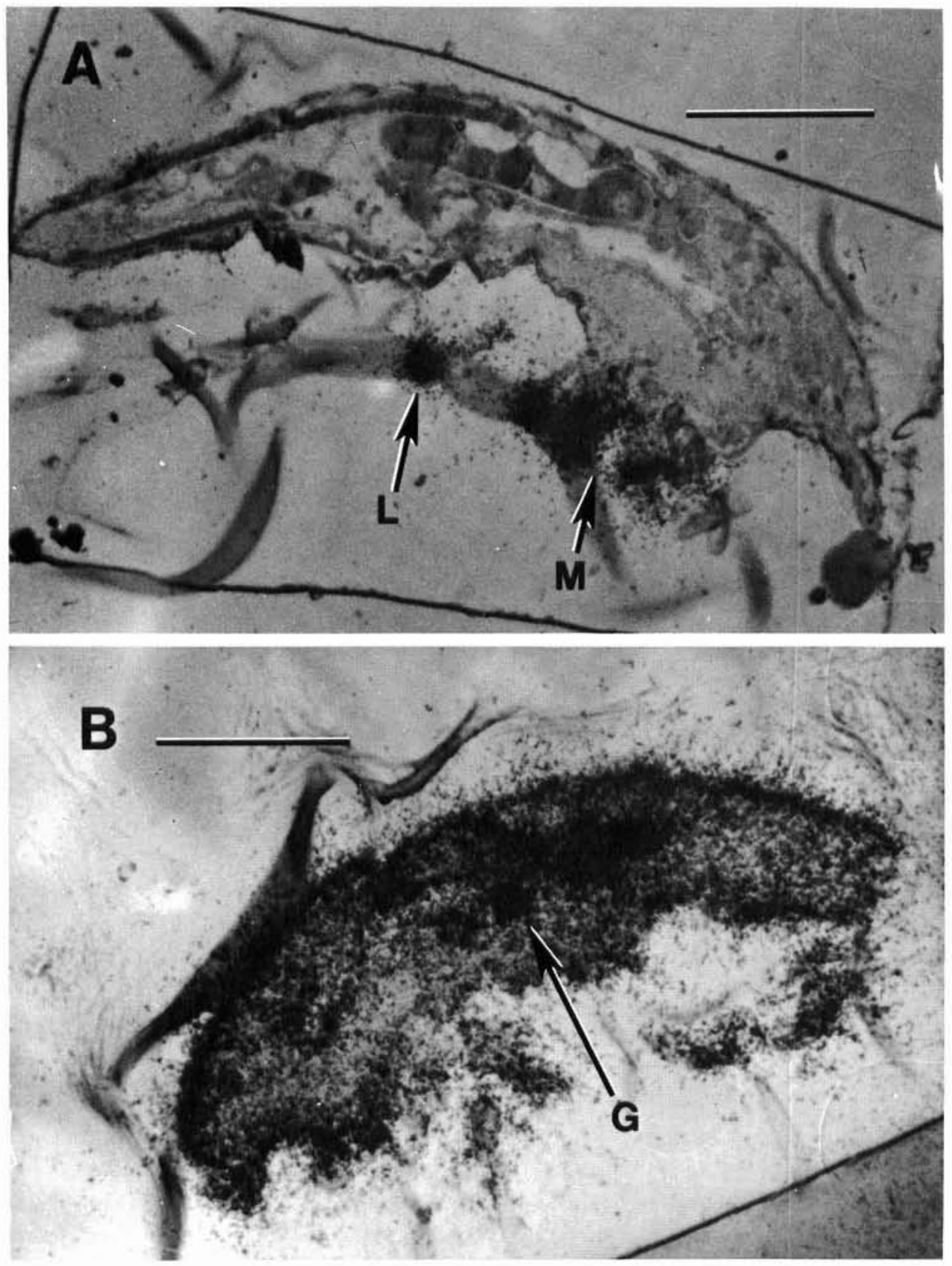

Fig. 7. Zausodes arenicolus. Autoradiography on sections of an individual from an intact core of sediment. Scale bars $=100 \mu \mathrm{m}$. (A) Following incubation with $\left[{ }^{14} \mathrm{C}\right]$-acetate; note development of silver grains around the mouth parts (M) and legs (L). (B) Following incubation with $\left[{ }^{14} \mathrm{C}\right]$ bicarbonate; radioactivity is distributed throughout the inside of the copepod, but particularly concentrated in the gut (G) suggests that not all Zausodes pairs were continuously joined over the incubation periods used in this study.

Considered collectively, the results of this study indicate that uptake of ${ }^{14} \mathrm{C}$ from $\left[{ }^{14} \mathrm{C}\right]$-bicarbonate by copepods in intact cores of sediment was the consequence of grazing on labeled microalgae. Uptake of ${ }^{14} \mathrm{C}$ from $\left[{ }^{14} \mathrm{C}\right]$-acetate, however, did not result from grazing on labeled bacteria but was due almost entirely to the metabolic activity of epicuticular bacteria. Anderson \& Stephens (1969) reached a similar conclusion in their study of uptake of labeled organic substrates by planktonic crustaceans. They concluded that uptake by a variety of crustaceans of $\left[{ }^{14} \mathrm{C}\right]$-amino acids, -glucose, and -acetate was due almost entirely to the activity of epicuticular bacteria.

Interestingly, epicuticular bacteria on Robertsonia sp., the largest of the 3 species considered here, took up much less radioactivity from $\left[{ }^{14} \mathrm{C}\right]$-acetate than did bacteria on either Zausodes arenicolus or Halicyclops coulli (Fig. 2B). The reason for this apparent inconsistency is unclear. SEM examinations indicated that at least as many, and possibly more bacteria were attached to the cuticle of Robertsonia sp. relative to the other 2 species. Further, since only adults of all 3 

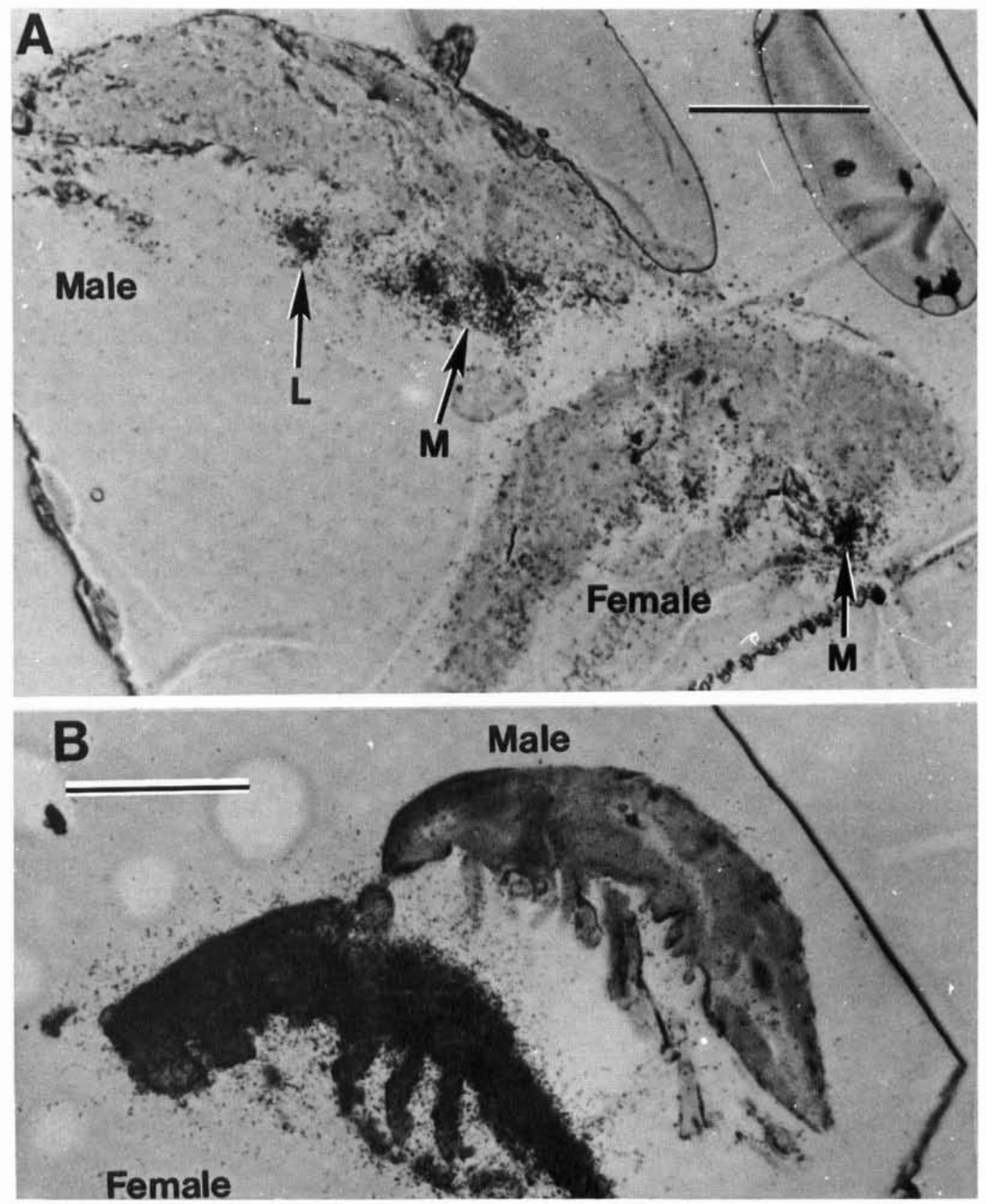

Fig. 8. Autoradiography on sections of clasping pairs of Zausodes arenicolus from an intact core of sediment. Scale bar $=100 \mu \mathrm{m}$. (A) Following incubation with $\left[{ }^{14} \mathrm{C}\right]$-acetate; note development of silver grains around mouth parts (M) and legs (L). (B) Following incubation with $\left[{ }^{14} \mathrm{C}\right]$-bicarbonate; radioactivity is associated only with the female, and is distributed throughout the inside of the copepod

species were used (which represents the terminal molt for copepods), there is no reason to suspect that the lower uptake of radioactivity by epicuticular bacteria on Robertsonia sp. was due to interspecific differences in the age of cuticles. It is possible that the ectocommensal bacteria species on Robertsonia sp. differ from those on $Z$. arenicolus or $H$. coulli, and have a different affinity for acetate. Sochard et al. (1979) reported that bacterial species associated with Acartia tonsa, a calanoid copepod, varied with habitat. I am unaware, however, of any studies that have attempted to determine if sympatric copepod species harbor different species of ectocommensal bacteria. Another possibility is that bacteria on Robertsonia sp. are simply less active, for reasons unknown, than bacteria on other copepod species. All 3 copepod species are essentially 
epibenthic (own obs.), and thus it seems unlikely that the relatively small amount of $\left[{ }^{14} \mathrm{C}\right]$-acetate taken up by epicuticular bacteria on Robertsonia sp. was due to an availability of substrate that differed from the other 2 species. The latter possibility seems particularly unlikely given that Robertsonia sp. took up much more ${ }^{14} \mathrm{C}$ from $\left[{ }^{14} \mathrm{C}\right]$-bicarbonate than did the other 2 species (Fig. 3), yet both $\left[{ }^{14} \mathrm{C}\right]$-acetate and $\left[{ }^{14} \mathrm{C}\right]$-bicarbonate were injected at the same vertical position in cores of sediment.

The results of this study bear on Montagna's (1984b) study of meiofaunal-microbial competition for dissolved organic material. Montagna concluded that various meiofaunal taxonomic groups (nematodes, ostracods, copepods) were able to take up $\left[{ }^{14} \mathrm{C}\right]$-glucose at velocities equivalent to or greater than that of sedimentary bacteria. Montagna dismissed the possibility that bacteria associated with meiofauna were responsible for the observed meiofaunal uptake of $\left[{ }^{14} \mathrm{C}\right]$-glucose. He reasoned that $\ldots$ the biomass of these [epicuticular or gut] bacteria are proportionately insignificant when compared to the biomass of the invertebrate. Unless these meiofaunal-associated bacteria are metabolizing at much greater rates than sediment-associated bacteria, these bacteria could not represent a significant proportion of meiofaunal uptake based on a weight-specific basis' (p. 187). Montagna \& Bauer (1988), however, noted that, for nematodes incubated with $\left[{ }^{3} \mathrm{H}\right]$-thymidine in sterile seawater, bacteria associated with nematodes were responsible for 35 to $40 \%$ of uptake of ${ }^{3} \mathrm{H}$. Although Montagna \& Bauer did not determine uptake of radioactivity by meiofaunaassociated bacteria during actual grazing experiments, their observation is consistent with the findings of this study, i.e. meiofauna-associated bacteria may be responsible for a large fraction of the radioactivity taken up by 'meiofauna' during grazing studies. A reliable determination of whether or not epicuticular bacteria are considerably more active than sedimentary bacteria will require further investigation.

In conclusion, the data presented here indicate that uptake of radioactivity from $\left[{ }^{14} \mathrm{C}\right]$-acetate by meiobenthic copepods during grazing studies does not reflect grazing on labeled sedimentary bacteria, but is due almost entirely to uptake by epicuticular microorganisms. Carman \& Thistle (1985) used ${ }^{14} \mathrm{C}$-acetate and ${ }^{14} \mathrm{C}$-bicarbonate to study dietary selectivity among cooccurring copepod species; Carman et al. (1989) also used these labeled substrates in their investigation of the effects of methods of label introduction on uptake of label by benthic copepods. In light of the findings reported here, the among-species and amongmethods differences in uptake of ${ }^{14} \mathrm{C}$ from labeled acetate reported by Carman \& Thistle (1985) and Carman et al, (1989) were apparently due to differences in uptake by epicuticular bacteria, not grazing on labeled bacteria.

The observation from autoradiographs that essentially no radioactivity from $\left[{ }^{14} \mathrm{C}\right]$-acetate was observed in the guts of copepods, is, however, intriguing in its own right. The lack of radioactivity in copepod guts could be interpreted as an indication that sedimentary bacteria are not an important food resource for the copepods in this study. Alternatively, the lack of radioactivity in copepod guts could be simply a consequence of the fact that only a small proportion (ca $2 \%$ ) of sedimentary bacteria are labeled by $\left[{ }^{14} \mathrm{C}\right]$-acetate (Carman 1990). Stated differently, the low specific activity of bacteria may have precluded detection of their consumption by copepods in this study. The resolution of this uncertainty has important implications for understanding the structure of benthic food webs. It is worth noting that the available evidence suggests that the low percentage of labeled sedimentary bacteria is not unique to labeled acetate; Carman (1990) also found that only $2 \%$ of sedimentary bacteria at this site use $\left[{ }^{3} \mathrm{H}\right]$-thymidine. Similar observations have been made at different locations and with various labeled organic substrates (Meyer-Reil 1978, Novitsky 1983). Thus, the inability to evenly label sedimentary bacteria may represent a serious limitation to meiobenthic, radiotracer-feeding studies.

In contrast to $\left[{ }^{14} \mathrm{C}\right]$-acetate, uptake of label from $\left[{ }^{14} \mathrm{C}\right]$-bicarbonate by copepods was apparently due almost entirely to grazing on labeled microalgae. Thus, $\left[{ }^{14} \mathrm{C}\right]$-bicarbonate would appear to be a useful tracer for studying the importance of microalgae as a food resource for other taxa living in association with sediments. Observations from the autoradiographic study, however, suggest that some copepod species are able to digest and assimilate microalgal biomass while others are not. Specifically, radioactivity from $\left[{ }^{14} \mathrm{C}\right]-$ bicarbonate was distributed throughout the body of Zausodes arenicolus and Robertsonia sp., whereas radioactivity in Halicyclops coulli was present only in 'packages' in the gut. Is this observation a reflection of Halicyclops' inability to digest microalgae? Autoradiographic studies performed in concert with enzymatic studies (e.g. Faubel \& Meyer-Reil 1983) could provide a useful approach for determining the food resources that are exploited by various meiofaunal species.

Acknowledgements. The manuscript was improved by comments from D. Balkwill, W. Burnett, P. LaRock, S. Meyers, P. Montagna, D. Simberloff, D. Thistle, and an anonymous reviewer. B. Felgenhauer, K. Riddle, and S. Silvers provided instruction on the use of the ultramicrotome. K. Riddle and S. Silvers assisted with the SEM. P. LaRock provided unrestricted access to his laboratory. This paper was extracted from a dissertation submitted to The Florida State University, and is contribution no. 1058 of the FSU Marine Laboratory. 


\section{LITERATURE CITED}

Anderson, J. W., Stephens, G. C. (1969). Uptake of organic material by aquatic invertebrates. VI. Role of epiflora in apparent uptake of glycine by marine crustaceans. Mar. Biol. 4: 243-249

Barnett, P. R. O. (1968). Distribution and ecology of harpacticoid copepods of an intertidal mudflat. Int. Revue ges. Hydrobiol. Hydrogr. 53: 177-209

Benson, A. A., Lee, R. F., Nevenzel, J. C. (1973). Wax esters: major marine metabolic energy sources. Biochem. Soc. Symp. 35: 75-187

Brock, T. D. (1978). The poisoned control in biogeochemical investigations. In: Krumbein, W. E. (ed.) Environmental biogeochemistry and geomicrobiology. Ann Arbor Science, Ann Arbor, Michigan, p. 717-725

Brown, T. J., Sibert, J. R. (1977). Food of some benthic harpacticoid copepods. J. Fish. Res. Bd Can. 34: 1028-1031

Carman, K. R. (1990). Radioactive labeling of a natural assemblage of marine sedimentary bacteria and microalgae for trophic studies: an autoradiographic study. Microb. Ecol. 19: 279-290

Carman, K. R., Dobbs, F. C., Guckert, J. B. (1989). Comparison of three techniques for administering radiolabeled substrates to sediments for trophic studies: uptake of label by harpacticoid copepods. Mar. Biol. 102: 119-125

Carman, K. R., Thistle, D. (1985). Microbial food partitioning by three species of benthic copepods. Mar. Biol. 88: $143-148$

Conover, R. J., Francis, V. (1973). The use of radioactive isotopes to measure the transfer of materials in aquatic food chains. Mar. Biol. 18: 272-283

Dahms, H.-U. (1988). Development of functional adaptation to clasping behaviour in harpacticoid copepods (Copepoda, Harpacticoida). Hydrobiologia 167/168: 505-513

Dobbs, F. C., Guckert, J. B., Carman, K. R. (1989). Comparison of three techniques for administering radiolabeled substrates to sediments for trophic studies: incorporation by microbes. Microb. Ecol. 17: 237-250

Faubel, A., Meyer-Reil, L.-A. (1983). Measurement of enzymatic activity of meiobenthic organisms: methodology and ecological application. Cah. Biol. mar. 24: 35-49

Felgenhauer, B. E. (1987). Techniques for preparing crustaceans for scanning electron microscopy. J. Crust. Biol. 7 : $71-76$

Findlay, R. H., White, D. C. (1984). In situ determination of metabolic activity in aquatic environments. Microbiol. Sci. 1: $90-95$

Gehron, M. J., White, D. C. (1982). Quantitative determination of the nutritional status of detrital microbiota and the grazing fauna by triglyceride glycerol analysis. J. exp. mar. Biol. Ecol. 64: 145-158

Guckert, J. B., Antworth, C. P., Nichols, P. D., White, D. C. (1985). Phospholipid, ester-linked fatty acid profiles as reproducible assays for changes in prokaryotic community structure of estuarine sediments. Fedn Eur. Microbiol. Soc. (FEMS) Microb. Ecol. 31: 147-158

This article was presented by Professor S. P. Meyers, Baton Rouge, Louisiana, USA
Gyllenberg, G., Lundqvist, G. (1978). Utilization of dissolved glucose by two copepod species. Ann. Zool. Fennici 15: 323-327

Hollibaugh, J. T., Fuhrman, J. A., Azam, F. (1980). Radioactively labeling of natural assemblages of bacterioplankton for use in trophic studies. Limnol. Oceanogr. 25: 172-181

Kern, J. C., Edwards, N. A., Bell, S. S. (1984). Precocious clasping of early copepodite stages: a common occurrence in Zausodes arenicolus Wilson (Copepoda: Harpacticoida). J. Crust. Biol. 4: 261-265

Lopez, G., Riemann, F., Schrage, M. (1979). Feeding biology of the brackish-water oncholaimid nematode Adoncholaimus thalassophygas. Mar. Biol. 54: 311-318

Meyer-Reil, L.-A. (1978). Autoradiography and epifluorescence microscopy combined for the determination of number and spectrum of actively metabolizing bacteria in natural waters. Appl. environ. Microbiol. 36: 506-512

Meyer-Reil, L.-A., Faubel, A. (1980). Uptake of organic matter by meiofauna organisms and interrelationships with bacteria. Mar. Ecol. Prog. Ser. 3: 251-256

Montagna, P. A. (1983). Live controls for radioisotope tracer food chain experiments using meiofauna. Mar. Ecol. Prog. Ser. 12: 43-46

Montagna, P. A. (1984a). In situ measurement of meiobenthic grazing rates on sediment bacteria and edaphic diatoms. Mar. Ecol. Prog. Ser. 18: 119-130

Montagna, P. A. (1984b). Competition for dissolved glucose between meiobenthos and sediment microbes. J. exp. mar. Biol. Ecol. 76: 177-190

Montagna, P. A., Bauer, J. E. (1988). Partitioning radiolabeled thymidine uptake by bacteria and meiofauna using metabolic blocks and poisons in benthic feeding studies. Mar. Biol. 98: 101-110

Novitsky, J. A. (1983). Heterotrophic activity throughout a vertical profile of seawater and sediment in Halifax Harbor, Canada. Appl. environ. Microbiol. 53: 2368-2372

Rogers, A. W. (1977). Techniques of autoradiography. Elsevier/North-Holland Biomedical, New York

Sochard, M. R., Wilson, D. F., Austin, B., Colwell, R. R. (1979). Bacteria associated with the surface and gut of marine copepods. Appl. environ. Microbiol. 37: 750-759

Stewart, M. G. (1979). Absorption of dissolved organic nutrients by marine invertebrates. Oceanogr. mar. Biol. A. Rev. 17: 163-192

Tempel, D., Westheide, W. (1980). Uptake and incorporation of dissolved amino acids by interstitial Turbellaria and Polychaeta and their dependence on temperature and salinity. Mar. Ecol. Prog. Ser. 3: 41-50

White, D. C., Davis, W. M., Nickels, J. S., King, J. D., Bobbie, R. J. (1979). Determination of sedimentary microbial biomass by extractible lipid phosphate. Oecologia (Berl.) 40: $51-62$

Williams-Howze, J., Silverman, H., Fleeger, J. W. (1987). Internal morphology related to tube-building in the meiobenthic copepod Pseudostenhelia wellsi. J. Crust. Biol. 7: 171-181

Manuscript first received: May 24, 1990

Revised version accepted: August 6, 1990 